\title{
MARGINALISERET TID
}

Materialitet, fremtid og håb i Georgien

\section{MARTIN DEMANT FREDERIKSEN}

Kystbyen Batumi i det vestlige Georgien er blevet udset af den georgiske regering til at blive et turistmekka i sortehavsregionen. Storslåede byggeprojekter kan ses overalt i bymidten - hoteller, restauranter, statuer, forlystelser og ikke mindst springvand. Såkaldte „franske springvand“, eller dansende fontæner, er blevet placeret tre centrale steder i byen, hvor de dominerer deres omgivelser med kaskader af vand, der skydes mod himlen i takt med lys og insisterende musik. Springvandene blev bygget af præsident Mikheil Saakashvili som en del af den generelle renovering af Batumi, der blev påbegyndt $i$ årene efter Rosenrevolutionen i 2003. Millioner blev brugt på disse og lignende projekter, der af regeringen blev beskrevet som tegn på fremskridt, visuelle påmindelser om den lyse fremtid, der lå forude for landet efter revolutionen (Le Moulec 2010). I en tale, afholdt kort før byggeriet af springvandene i Batumi blev sat i gang, fremhævede Saakashvili, at:

Fortidens Georgien var en nation, hvor hverken ledere eller folket kunne tro på fremtiden. Jeg tror, det er lykkedes os at ændre den opfattelse. Jeg tror, at det er lykkedes os at tilbyde håb. Jeg tror, det er lykkedes at vise styrke over for enorme udfordringer. Og jeg tror, at vi har en vision, der kan transformere en nation og en hel region (Saakashvili 2004; min oversættelse).

For 20-årige Vanya har der dog ikke været meget positivt - hverken ved springvandene eller præsidentens andre projekter. Han blev arbejdsløs efter krigen mellem Rusland og Georgien i sommeren 2008, og hans planer om at flytte til Rusland for at tage en uddannelse i Moskva faldt til jorden. Vanya var en af mine hovedinformanter under et feltarbejde udført fra 2008 til 2009 blandt en gruppe unge mænd i Batumi. For Vanya og hans venner var hverdagen ofte præget af kedsomhed. Det meste af deres tid blev brugt på at gå rundt i Batumis gader, som et tidsfordriv og for at mødes med venner og bekendte, der ligeledes slentrede 
rundt. Når vi gik sammen gennem byen, omtalte han jævnligt springvandene $\mathrm{i}$ meget negative termer og nægtede ofte at stoppe og kigge på dem. Selv om springvandene skulle symbolisere en lovende fremtid, var det ikke en fremtid, som Vanya følte, at han var en del af. Præsidentens nationale projekt syntes ikke at være et, der vedrørte ham. Vanya var ikke alene om at have denne opfattelse. Under mit feltarbejde var springvandene og de mange statslige byggeprojekter i byen et tilbagevendende emne, når lokale talte om fremtiden og deres mistillid til den. Men hvorfor blev løfter om en lovende fremtid mødt med en sådan skepsis?

Denne artikel undersøger, hvordan materialitet i det offentlige rum, her statslige byggeprojekter, kan medvirke til at underminere troen på fremtiden blandt lokalbefolkningen, på trods af at „tro på fremtiden“ netop er byggeprojekternes formål. Antropologen Anna Tsing har i sit studie af forholdet mellem et lille indonesisk lokalsamfund og den indonesiske stat vist, hvordan statslige projekter kan være medvirkende til (utilsigtede) marginaliserende processer (Tsing 1993). Denne artikel argumenterer for, at dette blandt andet har et tidsligt aspekt. Det vil sige, at marginalisering kan være et spørgsmål om ikke at tilhøre den samme tid, et fænomen, jeg vil henvise til som manglende „sam-tidighed“. Dette gør sig især gældende i forhold til spørgsmålet om ikke at tilhøre fremtiden. Gennem artiklen argumenterer jeg for, at mistilliden til byggeprojekterne kan ses som et udtryk for en form for tidslig marginalisering, hvor staten og dele af den georgiske befolkning ophører med at være hinandens ,sam-tidige“, fordi bygningerne repræsenterer en fremtid, som mange lokale ikke føler, de tilhører. Centralt for dette er samspillet mellem ændringer i opfattelser af ideen om den postsovjetiske „transition“"og statens evne til at distribuere håb for fremtiden blandt befolkningen, eksempelvis gennem materielle ændringer af det offentlige rum. For at forstå denne ændring sammenligner jeg i artiklen statslige byggeprojekter fra to tidspunkter - før og efter revolutionen i Georgien i 2003 - og den måde, byggeprojekterne bliver omtalt på lokalt i disse perioder.

\section{Materialitet og transition}

Som James Scott har vist i sin analyse af statslige projekter i Rusland, Tanzania og Brasilien, er omfattende planer om forbedring ofte endt galt, fordi de ikke har taget tilstrækkelig højde for lokale forhold (Scott 1998). Ikke desto mindre har omfattende materielle ændringer i og af det offentlige rum gennem århundreder været en måde, hvorpå stater og regeringer har søgt at legitimere sig selv i nutiden ved at skabe håb for deres befolkninger ved at vise, at forandringer var på vej (Harvey 2000). Dette har i høj grad gjort sig gældende i store dele af den postsovjetiske region i relation til den såkaldte „transition“. 
Begrebet transition blev vidt anvendt inden for en lang række fagområder til at forklare den situation, som en række nye lande befandt sig i efter Sovjetunionens sammenbrud i 1991 - en overgang fra sovjetisk planøkonomi til det frie marked. Som en række antropologiske studier af den postsocialistiske verden har vist, var transitionen på ingen måde entydig, og den udfoldede sig vidt forskelligt i de nye nationer. I en række af disse har tiden efter Sovjet været mærket af udbredt kaos og tab af muligheder, snarere end den har været en entydig vej mod en bestemt fremtid (Nazpary 2001; Humphrey 2002; Pedersen \& Højer 2008; Frederiksen 2011b; Louw 2011). Transitionen var mange steder præget af en vis dobbelthed $\mathrm{i}$ forhold til lokale forestillinger om fremtiden. På den ene side lå fremtiden åben, hvilket skabte håb om, at livet ville ændre sig til det bedre. På den anden side var den usikkerhed, som denne åbne fremtid repræsenterede, også tyngende (Verdery 1996; Dunn 2008; Svašek 2008). Dette var især tilfældet i Georgien, hvor borgerkrig, økonomisk tilbagegang, sammenbrud af statslige institutioner og politisk ustabilitet var en del af hverdagen i store dele af halvfemserne (Dudwick 2002; Frederiksen 2006).

Den nyvundne selvstændighed fandt også materielle udtryk i mange af de postsovjetiske lande, heriblandt Georgien. Dette skete ikke mindst i form af ikonoklasme, hvor statuer af Lenin og Stalin blev revet ned, men også gennem en række små og store nybyggerier, der symboliserede tilstedeværelsen af nye former for privat ejendom og nye internationale investeringer (Yampolsky 1995; Oushakine 2009; Alexander et al. 2007). Som Caroline Humphrey har påpeget, medførte den postsovjetiske periode ændringer i opfattelsen af det offentlige rum. Bygninger, der før var „,vores“, blev i takt med privatisering „,deres“, hvilket opdelte samfundet på nye måder (Humphrey 2007:178). Men selv om nye former for materialiter og ejerskab opstod, blev disse, i takt med ideen om „transition“ og den åbne fremtid, ikke udelukkende set som negative faktorer. På trods af den usikkerhed, de var omgivet med, blev de set som værende tiltag, der potentielt set gjorde fremtiden anderledes og bedre end den kaotiske nutid.

\section{Tomhed og åbenhed}

Omkring årtusindskiftet udførte antropologen Mathijs Pelkmans et feltarbejde i Batumi. På dette tidspunkt blev den autonome republik Ajara, hvori Batumi ligger, styret af den despotiske leder Aslan Abashidze. Politi, militær, erhvervsliv og handel ved den nærliggende tyrkiske grænse kom i stigende grad under Abashidzes direkte kontrol, og imens borgerkrige brød ud i andre georgiske regioner, formåede Abashidze op gennem halvfemserne at opretholde en høj grad af autonomi fra den centrale regering i hovedstaden Tbilisi. 
En lang række halvtomme bygninger stod dengang rundtomkring i byen. Pelkmans argumenterer for, at disse bygninger og deres tomhed kan bruges til at forstå transition i forhold til ideer om fremtiden (Pelkmans 2006). På det tidspunkt, hvor Pelkmans udførte sit feltarbejde, strømmede nye goder, idealer og mennesker over grænsen fra Tyrkiet, hvilket umiddelbart pegede på ændringer i det politiske og $ø$ konomiske liv. Udbredt nepotisme og statskontrol indikerede dog til stadighed en vis kontinuitet med sovjetiske praksisser (op.cit.144). Denne spænding, skriver han, var mest synlig i de „billeder på transition“, der blev skabt af lokalregeringens byggeprojekter. Officielle brochurer beskrev med stolthed de skoler, kirker, stadioner, fabrikker, børnehaver, hospitaler og kulturhuse, som Aslan Abashidzes politiske parti havde bygget både i Batumi og andre steder i regionen.

Et fællestræk ved mange af disse modernistiske byggeprojekter var, at de af forskellige grunde var blevet opgivet, og derfor enten stod som halvfærdige skeletter eller tomme bygninger. Det mest overraskende ved dette var, ifølge Pelkmans, at de til stadighed blev set som billeder på fremskridt blandt store dele af lokalbefolkningen. Et sigende eksempel i Pelkmans tekst er en børnehave, der blev bygget $\mathrm{i}$ Batumis centrum. Bygningen knejsede synligt over et omgivende hegn, malet $\mathrm{i}$ hvidt med dele af tagkonstruktionen i glas. Indenfor var børnehaven udsmykket i forskellige farver og indeholdt fuldt udstyrede legerum, soverum, computerrum og sågar en lille swimmingpool med tilhørende fodbade. Den skulle, ifølge bygningens arkitekt, gøre børnene „klar til livet i den nye verden“(op.cit.200). Det eneste, der faktisk manglede i børnehaven, var børn, på trods af at den havde stået færdig i to år. Var dette, spørger Pelkmans, fordi der havde været tale om dårlig planlægning og organisering? Var det et levn fra tidligere tiders form for centraliserede beslutningsprocesser, hvor ideerne passede dårligt til praksis? Børnehaven figurerede i Aslan Abashidzes statslige brochurer om fremskridtet i regionen, men til Pelkmans' overraskelse viste det sig, at børnehaven faktisk var finansieret af direktøren for havnen, og at den var ment som et tilbud til havnemedarbejdernes børn. Hvad alle refererede til som et statsligt projekt, var dermed i realiteten en privatskole, som få i realiteten ville have adgang til. Bygningen var dog delvist statslig som følge af de flydende grænser mellem den offentlige og private sektor, hvidvaskning af penge og korrupt politiske netværk og blev af selve staten kontinuerligt fremsat som et bevis på statens succes.

Byggeriets status og ejerskabsforhold var således lige så uklar som den politisk-økonomiske kontekst og lige så uigennemskuelig som transitionens retning (op.cit.205). Ikke desto mindre blev børnehaven omtalt i overvejende positive vendinger af de lokale, som Pelkmans talte med. De nye byggerier i byen var i deres øjne et udtryk for, at tingene trods alt var ved at forandre sig til det bedre, og at fremtiden ville gøre drømme til virkelighed. Bygningernes tomhed, skriver 
Pelkmans, kan forstås som en forudsætning for at opretholde denne drøm om en bedre fremtid. Så længe de var tomme, tilhørte de fremtidens sfære, og de var derfor potentielt set åbne for alle (op.cit.207). Deres tomhed lod fremskridtets ulighed forblive uset, og en tom børnehave afslørede eksempelvis ikke det faktum, at den kun var ment som et tilbud til en udvalgt gruppe. For Pelkmans' informanter gjorde dette sig gældende både i forhold til de færdige, men aldrig anvendte, bygninger og de halvfærdige konstruktioner.

Vanya, den unge mand præsenteret tidligere, voksede op i ovenstående periode. Faderen døde, da Vanya var lille, og storebroderen migrerede få år senere til Moskva, hvor han blev boende. Dette efterlod Vanya alene i Batumi med sin mor. De havde meget få penge, og Vanya begyndte sammen med nogle venner at stjæle, først mad, så små metaldele, som de solgte videre, og senere bilradioer. Det var dog, med hans egne ord, primært „for sjov“. Det var det også, da han begyndte at ryge marihuana. Tyveriet ophørte, men rygningen fortsatte gennem en årrække. Det lykkedes ham ikke at få en uddannelse på grund af pengemangel, og selv om moderen arbejdede, var de afhængige af de penge, som storebroderen nu og da formåede at sende hjem fra Moskva. Vanya omtalte ofte retrospektivt halvfemserne som „mørke tider“. Det var først langt senere, at han havde opdaget, hvordan Abashidze havde ledet regionen. Som han forklarede i et interview: „Dengang var der mange, der troede, at han var en god mand, også min mor og jeg. Mange kendte ikke så meget til ham. Han var en god mand i vores øjne." Selv om Vanyas opvækst havde været præget af fattigdom, kriminalitet og stofmisbrug, var den for Vanya ikke som sådan bemærkelsesværdig, ,det var Georgien", og for ham havde livet aldrig set anderledes ud. Han havde som barn ikke oplevet det som spektakulært, at der var en fabrik, der producerede narkotika, ved siden af det sted, hvor han fangede frøer.

Byggeprojekterne, som Pelkmans beskriver, havde også i Vanyas øjne dengang været positive tegn på fremskridt. Når vi sammen gik rundt i byen, kom vi fra tid til anden forbi dem. Men nu var de snarere ruiner, end de var symboler på fremtiden. På få år var både Abashidze og hans byggeprojekter blevet gjort til fortid.

\section{Den afsluttede transition}

I 2004 blev den daværende georgiske præsident Eduard Sjevardnadze afsat under en ikke-voldelig revolution, almindelig kendt som „Rosenrevolutionen“. Titusindvis af mennesker havde demonstreret $i$ hovedstadens gader, blandt andet anført af den unge advokat Mikheil Saakashvili. Da et nyt valg blev udskrevet i starten af 2004, vandt Saakashvili med over 92 procent af stemmerne bag sig 
(Manning 2007). Ordene „håb“ og „,fremtid“"var fra starten en del af Saakashvilis nationale agenda og politiske retorik. Da Saakashvili kom til magten, var det således med store løfter om forandring. Ved sin tiltrædelse og i flere efterfølgende taler erklærede den nye præsident, at transitionen i Georgien nu endelig var ovre (Saakashvili 2004). Få måneder senere og efter massivt politisk pres blev Aslan Abashidze tvunget til at flygte til Rusland, og Ajara kom igen under den georgiske regerings kontrol. Regionen opretholdt sin status som autonom republik, men $\mathrm{i}$ praksis havde lokalregeringen nu meget begrænset selvbestemmelse. Det var i denne periode, at opførelsen af springvand og andre nybyggerier i Batumi blev påbegyndt. Op imod 200 millioner kroner blev efter sigende afsat til renoveringen af Batumi, men det forblev i lang tid uklart, præcis hvad de skulle bruges til. Facader på en række bygninger i centrum af byen blev malet, som det allerede var sket i Tbilisi (Frederiksen 2011b; Manning 2007), og det nye georgiske flag begyndte at vaje ved siden af det ajariske på og ved offentlige pladser og bygninger. Enkelte af Aslan Abashidzes (ufærdige) byggeprojekter blev revet ned, mens andre blev solgt som del af en større privatisering. Ligesom mange Sovjet-monumenter var blevet fjernet for at symbolisere Sovjetunionens sammenbrud, blev Abashidzes byggerier nu fjernet for at symbolisere, at hans tid - og transitionen - var ovre. I stedet skød en lang række nye byggerier i vejret i og uden for byen, mest af alt hoteller. Disse skulle, i teorien, sikre et boom inden for turisme og derved skabe et økonomisk grundlag i byen, der ikke var præget af den korruption, nepotisme og tvetydige grænsehandel, der havde præget Abashidzes tid.

\section{Frem til fortiden}

Ideen om at gøre Batumi til et center for turisme var ikke ny. Som et af de eneste subtropiske områder i hele Sovjetunionen havde den georgiske sortehavskyst tidligere været et yndet feriemål. Dette gjaldt især for ledende medlemmer af kommunistpartiet. De byggede storslåede „dachaer“- sommerhuse - langs strandene og på de grønne bjergskråninger. Kyststrækningen var blandt andet et yndet mål for den georgiskfødte Josef Stalin, der tilbragte de fleste somre i en af sine dachaer, $\mathrm{i}$ håbet om at det ville forbedre hans skrantende helbred (Montefiore 2005:71ff.). Ydermere blev regionen og især Batumi et område, hvor ,Sovjetunionens helte“, det vil sige højt dekorerede militærpersoner, blev sendt til efter at være gået på pension, som en belønning for deres tjeneste. Klimaet og havet sikrede herudover regionen en plads i den sovjetiske planøkonomi som producent af citrusfrugter, te og tobak og som et centrum for uddannelse af søfolk. Som iagttagere senere har påpeget, var klimaet i Ajara-regionen ikke som sådan optimalt for hverken turisme eller dyrkning af citrus og te, men grundet den sikkerhed, jerntæppet gav, 
voksede te, som om Ajara var det vådeste sted på jorden, og citrus og turisme, som om det var det mest solrige (Pelkmans 2006:6). De faktiske forhold fraholdt dog ikke styret fra kontinuerligt at søge at udvikle regionen. Infrastrukturen og det offentlige rum i Batumi, der førhen primært havde fungeret som en oliehavn, ændrede sig markant som følge af tilstrømningen af turister, søfolk og pensionister. Efter sigende havde der sågar været planer om at fjerne et nærliggende bjerg med dynamit for at sikre, at de skyer, der samlede regn i bugten, kunne forsvinde. Dette blev dog aldrig ført ud i livet.

Med Sovjetunionens fald forsvandt jerntæppets ,sikkerhed“, og både turistindustrien og den lokale produktion af te og citrus blev stillet over for store udfordringer. De nye markeder mod vest viste sig hurtigt at være uden for rækkevidde, og den pludselige konkurrence med nabolandet Tyrkiet betød, at produktionen af te og citrus næsten stoppede. Vidtstrakte plantager blev opgivet, hvilket medførte et stort tab af arbejdspladser. I forhold til turisme var situationen også pludselig forandret. Folk havde nu mulighed for at tage til nye destinationer, og den ulmende borgerkrig i Georgien betød, at kun få turister fra de tidligere Sovjetrepublikker søgte mod den georgiske kyst. Enkelte georgiere fra andre regioner i landet søgte stadig til byen som turister. Men forholdet mellem de georgiske turister og lokale var til tider problematisk grundet de politiske spændinger mellem Abashidze og den georgiske regering i Tbilisi. Efter Abashidzes afsættelse i 2004 var håbet, at både flere georgiere og internationale turister igen ville begynde at komme til byen om sommeren. Med transitionens ,afslutning“ ville præsident Saakashvili genskabe Batumi som turistby og dermed sikre dens fremtid.

\section{Den afsluttede fremtid?}

I begyndelsen af august 2008, netop som årets turistsæson var ved at begynde, startede den væbnede konflikt mellem Rusland og Georgien. Allerede i løbet af de første dage flygtede størstedelen af turisterne fra Batumi, selv om konflikten på dette tidspunkt kun hærgede i den nordlige del af landet. Nogle strandede dog i byen, da russerne bombarderede en del af jernbanelinjen til hovedstaden. Da havnebyen Poti, beliggende få kilometer længere oppe ad kysten, ligeledes blev bombet, begyndte mange lokale at flygte op i bjergene. Grundet byens havn og en nærliggende militærbase frygtede de, at Batumi ville blive den næste by, der blev luftbombet. Russerne havde udpeget disse som strategiske mål.

Selv om konflikten var kortvarig, var resten af turistsæsonen ødelagt. Frygten for, at den skulle blusse op igen, afholdt både lokale og internationale gæster fra at tage til Batumi. Strande og hoteller lå næsten øde hen, og sammen med turisterne forsvandt store dele af de indtægter, som mange lokale havde regnet med. 
Ifølge en bekendt, der arbejdede som konsulent i det lokale „Ajara Tourism Association“, var det ikke blot denne sæson, der var spoleret. Chancerne for, at internationale turister ville søge mod Georgien og Ajara i de følgende år, var minimale. Som han på et tidspunkt udtalte: „Det eneste positive, vi kan sige om krigen, er, at folk ude i verden nu ved, hvor Georgien ligger, på grund af den massive mediedækning. Det negative er, at ingen længere tør komme hertil.“

Det var i disse uger, jeg første gang mødte Vanya. Han var tjener på en af de eneste cafeer ved stranden, der forblev åben under krigen. Jeg kom på cafeen som en af få gæster og begyndte at bruge aftenerne på at sidde og tale med Vanya og det resterende personale. Grundet mangel på turister og gæster blev cafeen dog snart nødsaget til at lukke. Den pludselige arbejdsløshed betød, at Vanya ikke kunne tage til Moskva, og selv hvis han havde haft de manglende penge, havde migration til Rusland været nærmest umulig på grund af den politiske situation, da visumreglerne mellem Georgien og Rusland efter krigen blev om end endnu mere strikse, end de havde været før (se Mühlfried 2010). Mulighederne i regionen var på dette tidspunkt få, og den generelle arbejdsløshed var overvældende. Selv om ingen officielle statistikker eksisterede, lå lokale skøn på mellem 50 og 70 procent. Fremtiden blev et emne, som Vanya ikke brød sig om at diskutere, og ved flere lejligheder blev han synligt irriteret over, at jeg spurgte ind til hans planer.

Vanya var ikke alene om dette. Hverdagen både for ham og for mange af hans jævnaldrende udspillede sig i en position, hvori de modtog meget lidt hjælp udefra. De var ikke berettigede til at få økonomisk bistand fra staten, og de havde ikke penge nok til at tage en uddannelse, hverken i udlandet eller på et lokalt universitet. Og selv om de havde meget få penge, var de ikke en del af målgruppen for de utallige internationale og lokale ngo'er i landet, da disse primært arbejdede med kvinder eller internt fordrevne flygtninge. Endvidere kom de fra sociale baggrunde, hvor mulig støtte fra deres familier var begrænset, primært på grund af fædre, der enten var alkoholiserede, migrerede eller døde (Frederiksen 2011a). For dem syntes transitionen ikke at være ovre, i den forstand at fremtiden var lige så uvis, som den altid havde været. Hvis landet havde nået sit mål, levede dette mål næppe op til de forventninger, der havde været til det blandt denne del af befolkningen.

Hverdagen for Vanya og hans venner blev et spørgsmål om tidsfordriv. Sammen gik vi rundt i gaderne, dag efter dag, i en nærmest endeløs vandring. Men selv om Vanyas liv, set fra hans egen synsvinkel, var gået i stå, så fortsatte præsidentens byggeprojekter i byen, som om intet var sket. 


\section{Nye bygninger, nye fremtider}

Planen for et nyt operahus blev fremført på et tidspunkt, hvor præsidenten var under massivt pres. Kritiske røster mente, at Saakashvili bar en stor del af ansvaret for krigen, og at krigen som sådan havde været unødvendig. Disse stemmer var ikke bare marginale, men havde skabt massive demonstrationer i hovedstaden, der fortsatte i flere måneder. Oppositionen påbegyndte en landsdækkende rundrejse med konvojer af biler og minibusser, der transporterede talere og demonstranter fra by til by. De plæderede for, at et valg skulle udskrives, ellers ville landet ende $\mathrm{i}$ endnu en revolution. Præsidenten selv tog også på tur. Han fulgte næsten samme rute og ankom i de samme byer som oppositionen, blot nogle uger efter, at de havde været der. Med sig havde han beroligende ord om, at krigen var ovre, og at russerne bar hele skylden, samt planer om nye byggeprojekter, der skulle sikre landets fremtid.

Han ankom også til Batumi, omringet af sin horde af tungt bevæbnede livvagter. Den officielle grund til besøget var præsentationen af planerne for et nyt operahus. Sloganet var ,et nyt operahus for alle“, et udtryk, der blev konkretiseret af det faktum, at operahusets facade løbende ville kunne skifte farve. Det var således det visuelle udtryk, der dannede den umiddelbare baggrund for det inklusive aspekt. Operahuset skulle placeres nær strandpromenaden på en plads, der tidligere havde huset et af Aslan Abashidzes byggerier. En stor plakat, med billede og slogan, blev sat op på den tomme byggetomt, og løftet gik på, at operahuset ville stå færdigt den følgende sommer.

I en tale holdt ved præsentationen forklarede præsidenten, at operahuset ville være „det mest grandiose i sortehavsregionen“. Ind imellem udtalelser om, at han ikke ville træde tilbage til trods for protesterne mod ham, fremhævede han, at regeringen ikke blot ville bygge et operahus i byen, den ville , heller ikke ville spare nogen indsats for at bekæmpe arbejdsløshed og fattigdom på Georgiens sortehavskyst“ (Mchedlishvili 2009; min oversættelse). På trods af situationen $\mathrm{i}$ de to andre autonome regioner i landet, Abkhasien og Sydossetien, hvis status var blevet om muligt endnu mere uklar efter konflikten med Rusland, og trods den spirende globale økonomiske krise fastholdt præsidenten, at Georgien fortsat var på rette kurs. Som han forklarede i sin tale:

Vi vil fuldføre dette projekt sammen og, som jeg har lovet, gøre Batumi til den smukkeste by ved Sortehavet. Mange vil sige: 'Der er ikke tid til operahuse og musikhuse, når fjenden står på vores jord, og når vi er sultne og arbejdsløse.' Men dette er en yderligere kilde til arbejde og et middel til at tiltrække turister. Hvis Ajara har 200.000 turister i dag, vil dette antal om to år være vokset til 1,5 millioner og om fem år til 4-6 millioner [...] Jeg garanterer dette, og jeg har aldrig løjet for jer. Når den fremtidige generation spørger, hvad vi har givet dem, vil de 
sige, at vi har opbygget det mest fremtrædende turistcentrum ved Sortehavet, det smukkeste operahus i Europa, et nyt Barcelona i Georgien, og hvad der er endnu vigtigere, et bedre liv (ibid.).

Operahuset var således ikke blot ment som gave til byens nutidige beboere, den var i lige så høj grad til fremtidens generationer. Men spørgsmålet om, hvem operahuset egentlig var til, forblev uklart for mange. Sloganet ,et nyt operahus for alle" var ikke som sådan et udtryk for, at alle nu ville kunne gå i operaen. Rent praktisk blev det bygget for turister. Det inkluderende syntes således snarere at bestå i, at alle ville kunne se operahuset udefra. Dette gjorde sig også gældende for en lang række af de andre byggeprojekter i byen. Under en køretur med min nabo Zauri, en tidligere maskiningeniør, der nu ernærede sig som taxachauffør, kom vi forbi en række konstruktioner lige uden for centrum. Til mit spørgsmål om, hvem der byggede hotellerne, svarede han hånligt, at det skam ikke var hoteller det hele. Enkelte af byggerierne var også til fast beboelse. Han nærmest spyttede, da han fortalte, hvad kvadratmeterprisen i en af lejlighederne ville være. Zauri havde $i$ en lang periode forgæves prøvet at finde arbejde som maskiningeniør, men fordi der næsten ingen fabrikker var i regionen længere, havde det været umuligt. Det var ikke meget nemmere at overleve som taxachauffør. Mange andre havde valgt den samme udvej, og Zauri forklarede, at han skulle være heldig, hvis han fik en, to eller tre korte ture rundt i byen på en dag. ,Benzin koster penge, bilen koster benzin, vedligeholdelse koster penge. Alting spiser penge her, så indkomsten er meget lille." Selv om byggerierne, vi passerede, stod tomme, var der for Zauri ingen tvivl om, hvem de var til, eller rettere, hvem de i hvert fald ikke var til - de var ikke til ham.

Denne opfattelse af, at byggeriernes fremtid tilhørte „nogle andre“, gik igen blandt de unge mænd, jeg fulgte, også når det angik hotellerne. De fremhævede, at de formodentlig aldrig selv ville komme til at bo på dem som gæster, men derudover mente de også, at det var tvivlsomt, hvorvidt de nogensinde ville komme til at arbejde på et af dem. At få arbejde på et af de nye hoteller krævede som minimum, at man havde taget kurser inden for restaurations- og hotelbranchen. Uden hverken uddannelse eller muligheden for at tage en var dette et håbløst projekt for unge som Vanya. Selv om kurserne blev udbudt flere steder, kostede de penge, og det udelukkede mange unge fra at kunne tage dem.

Batumis offentlige rum bestod på dette tidspunkt ikke blot af delvist færdige byggeprojekter. Det bestod også af utallige lyssektioner og projektorer, der oplyste officielt udvalgte steder - kirker, gamle romerske ruiner, russiske palæer fra slutningen af det 19. århundrede, palmetræer og officielle bygninger. Det er ikke overraskende, at lys blev en udbredt mekanisme til at symbolisere forandring efter revolutionen, i og med at elektricitetsmangel havde præget størstedelen af 
halvfemserne i landet (Devlin 2004). Elektricitet var et af Saakashvilis opnåede mål. De dansende springvand i Batumi var massivt oplyst, og blandt lokale sagdes det, at de var Saakashvilis „kæleprojekter“. Som en informants udtalte:

Ved du, hvad vi kalder ham? 'Kong Springvand d. 1.' Det eneste, han laver, er at bygge springvand. Ja, han har også bygget nogle veje og sørget for elektricitet, det er også godt, men hvad med noget mad?

Lige såvel som nogle ting og steder i byen blev oplyst, forblev andre i skyggen. Der blev således skabt en synlig afgrænsning mellem det, der kunne inkluderes i statslige ideer om nationen og dens fremtid, og det, der blev set som ubrugbart og derved gemt eller trukket ud af det offentlige rum (Frederiksen 2009). Og i takt med at de nye byggeprojekter, springvand og lyssektioner blev flere og flere, så voksede den lokale skepsis mod dem. Jeg spurgte Vanya, hvorfor han troede, at præsidenten ville bygge et operahus:

Jeg ved det ikke, det er ikke for min skyld. Det ville være bedre, hvis han ikke byggede det. Folk har økonomiske problemer, det ville være bedre, hvis Misha [præsidenten] gav pengene til folket, eller hvis han byggede nogle fabrikker for at skabe arbejdspladser. Men ikke et operahus, almindelige mennesker vil ikke kunne bruge det, det vil kun være for de rige.

Da jeg efterfølgende spurgte, om præsidenten da slet ikke havde gjort noget godt, svarede han nøgternt, at „før Misha havde vi et dårligt liv, da Misha kom, blev vi ved med at have et dårligt liv". På dette tidspunkt, knap et årti efter Mathijs Pelkmans observerede de tomme, håbefulde bygninger i Batumi, lå flere af de selvsamme bygninger stadig tomme hen. Deres tomhed syntes at bære præg af decideret hulhed. For mine informanter var dette steder, hvor de højst stoppede for at tisse (,det er som et stort toilet“, som en af dem påpegede), og hvor misbrugere mødtes for at være skjult fra offentlige øjne. De resterende af Aslan Abashidzes tomme eller ufærdige byggeprojekter stod nu som ruiner blandt en række nye ufærdige projekter, opført af Mikheil Saakashvili. Nogle af sidstnævnte, som operahuset, eksisterede endog ikke endnu, kun som billeder og slogans på store plakater sat op på deres bestemmelsessted. Men den fremtid, de skulle symbolisere, fandt ikke genklang hos lokalbefolkningen. Den håbefuldhed, som tidligere var blevet skabt af tomme eller halvfærdige bygninger under Abashidze, syntes at være blevet erstattet af en håbløshed, der voksede med hver ny bygning. Som Vanya udtrykte det, havde livet ikke ændret sig under Abashidze, hvorfor skulle det gøre det nu? 


\section{Stat, håb og materialitet}

Håb og tillid til staten er i en anden sammenhæng blevet beskrevet som centrale elementer i individers anskuelse af deres egen fremtid. I en analyse af relationen mellem stat og håb i Australien beskriver Ghassan Hage en libanesisk immigrant, Ali, og dennes møde med fodgængerfelter. Ali fortæller, hvordan disse fik ham til at føle sig betydningsfuld, i og med at de fik biler til at standse for ham. Det var en situation, han ikke havde været vant til i Beirut. Med fodgængerfelterne oplevede han, at der var nogen (staten), der passede på ham (Hage 2003:145). Det „,magiske“ ved fodgængerfelterne, skriver Hage, er det faktum, at de tilbyder et øjebliks anerkendelse. De kan således ses som en form for „social gave“, der får modtageren til at føle, at hun eller han er en del af samfundet (op.cit.146). Ifølge Hage er dette et udtryk for samfundets (eller statens) evne til at distribuere håb. Det vil sige, til at skabe steder, scenarier og mekanismer, der får samfundets medlemmer til at stole på det samfund, de lever i. Håb, skriver Hage, er generelt set en måde, hvorigennem folk, på forskellig vis, forholder sig til deres fremtid. At få en befolkning til at tro på samfundet ved at skabe håb hænger således sammen med evnen til at få denne befolkning til at tro på statens fremtid og ikke mindst deres egen placering i denne fremtid (op.cit.10ff.).

For immigranten Ali i Australien var fodgængerfeltet en social gave, der gav ham en oplevelse af, at han hørte til i samfundet, og at det anerkendte ham. Men hvilken form for social gave er springvandene og planerne for et nyt operahus i Batumi? Og hvordan adskiller de sig fra en tom børnehave? I den resterende del af artiklen diskuterer jeg dette i relation til forholdet mellem materialitet, tid og håb.

\section{Marginalisering og tidslige katarakter}

Mennesker og materialitet kan siges at eksistere i en form for gensidig afhængighed - mennesker skaber ting, der påvirker mennesker, der skaber ting (Miller 2005). Men som Christopher Pinney har påpeget, er dette ikke så enkelt og så cirkulært et billede, som det umiddelbart synes at være. Tilstedeværelsen af materialitet kan rigtignok skabe sammenhæng i hverdagen, men det kan lige såvel skabe uorden og adskillelse (Pinney 2005:257). Dette gør sig især gældende i forholdet mellem materialitet og tid. I sin analyse af denne relation henviser Pinney til den tyske filosof Siegfried Kracauer. Tid, skriver Kracauer, er ikke et homogent flow. Det skal, metaforisk set, snarere forstås som en form for katarakter: Tid er således ikke en enkelt flod, men derimod en række af fald og strømhvirvler, der alle forfølger deres egne usammenhængende baner (Kracauer 1969). Dette 
betyder, at ting, mennesker og fænomener således kan befolke den samme epoke uden nødvendigvis at være hinandens sam-tidige (Pinney 2005:265) - de har ikke nødvendigvis det flow eller det samme endemål. Selv om ting, mennesker og fænomener, ligesom vand i en række af fald, til en vis grad er forbundet med hinanden, eksisterer de ikke nødvendigvis i en direkte relation til hinanden. Dette perspektiv på tid er interessant i forhold til den beskrevne situation i Georgien, fordi den kan hjælpe til at give en forståelse af de forskellige oplevelser af og ideer om fremtiden, der er på spil.

Nationale narrativer, inklusive det, der bliver fremført af Mikheil Saakashvili, baserer sig som oftest på en idé om, at samfundet entydigt er på vej det samme sted hen, som en flod, der bevæger sig mod et fast defineret mål. I Georgien blev dette narrativ koblet til ideen om „transitionen“, som ifølge præsidenten nu var ovre. Efter 15 års postsovjetisk kaos havde landet, ifølge præsidenten, endelig fundet fodfæste. Men virkeligheden for store dele af befolkningen var mere kompleks end som så. For mange lokale, som Vanya og hans venner, bevægede samfundet sig snarere et andet sted hen end dem.

Som nævnt opfattede mine informanter eksempelvis ikke de nye hoteller som værende deres, De ville aldrig komme til at bo på dem, og selv hvis de blev bygget færdige (hvilket mange af dem ikke syntes at blive), var sandsynligheden for at få arbejde på et af dem minimal. Operahuset var, med præsidentens ord, en gave til fremtidens generationer. Problemet for mange lokale var, at de ikke var sikre på, at de var en del af denne fremtid. Ud over at operahuset som social gave kun eksisterede som en idé og som et billede på en plakat, blev det således heller ikke opfattet som en gave. Heri ligger en af de centrale forskelle mellem den umiddelbare postsovjetiske periode og den ,posttransition“periode, der retorisk blev fremsat af Saakashvili - det faktum, at tomheden som et rum af muligheder, som Pelkmans beskrev, ikke længere eksisterer som et symbol på en inklusiv fremtid. Da transitionen i Georgien blev erklæret for overstået af Saakashvili, stod fremtiden ikke længere som et åbent mulighedsrum med nutiden som et skridt på vejen. Det blev snarere gjort klart, hvad fremtiden ville være eller ej (og for hvem), hvilket omstyrtede den kalejdoskopiske arena, den før var blevet set som. Under mit feltarbejde var der stadig utallige byggeprojekter i Batumi, mange af dem overladt til tomhed efter krigen og den økonomiske krise, men de var ikke længere et billede på åbenhed. Selv løftet om bedre turistsæsoner i fremtiden blev af mange af mine unge informanter opfattet som hult grundet krigen. De befandt sig i stigende grad i en marginal position, hvor samfundet omkring dem gik én vej, mens de var tvunget til at gå en anden. 


\section{Fremtid for hvem?}

At bygge monumenter, skriver Mikheil Yampolsky (1995:95), kommer fra et ønske om på magisk vis at påvirke tidens gang, enten for at ændre den eller undgå dens indflydelse. At rive en statue af Lenin eller Stalin ned, som det skete i mange lande i starten af halvfemserne, var en offentlig erklæring af, at Sovjettiden var ovre. Som beskrevet kan nedrivningen af Aslan Abashidzes byggerier ses i samme lys. Det vil sige som et offentligt udtryk for, at Abashidzes tid var ovre. Skift i og demonstrationer af magt er indbygget i sådanne handlinger. Magten i det offentlige rum ligger dog ikke blot i omfattende handlinger som ikonoklasme, men også i langt mere sofistikerede design (Thrift 2004). Evnen eller magten til at tænde og slukke for en kontakt og derved oplyse én bygning, men ikke en anden, og derved bestemme, hvad der skal ses, og hvad der skal hvile i skyggen, er lige så stor. Denne artikel har fokuseret på, hvordan dette kan resultere i utilsigtede konsekvenser som følelser af marginalisering og manglende tro på staten og fremtiden.

Som Elizabeth Dunn har påpeget, forblev den georgiske stat efter revolutionen tilbagetrukket fra en lang række socioøkonomiske områder på trods af Saakashvilis forsøg på at reformere samfundet. Dette, skriver Dunn, skete ikke udelukkende, fordi den georgiske regering under Saakashvili fungerede under neoliberale principper om selvregulering, det var snarere et spørgsmål om en tabt kapacitet til at regulere mennesker og ting (Dunn 2008:244). Mens staten efter revolutionen således koloniserede nogle dele af det sociale liv (se Koch 2006), forblev andre „ukoloniserede, ikke-gennemtrængte og stort set forladte“ (Dunn 2008:253; min oversættelse). Som Paul Manning ligeledes har konstateret, er det svært at pege på synlige resultater af Saakashvilis politik ud over renoveringsprojekter, malede facader i hovedstaden og opfyldning af de mest hullede veje (Manning 2007:202). På trods af udviklingsprojekter i millionklassen er store sociale problemer endnu ikke blevet adresseret (Dunn 2008:254). Som vist i denne artikel er situationen i Georgien dog ikke blot et spørgsmål om en tabt evne til at regulere. Det er også et spørgsmål om en tabt evne til at skabe håb.

Springvandene og byggeprojekterne i Batumi og den lokale pessimisme mod dem skal ses i dette lys. De blev som nævnt gjort grin af som værende præsidentens „kæleprojekter“, der gjorde lidet andet end at forsøge at pynte på hans ry. Som beskrevet klagede flere lokale over, at springvandene ikke satte mad på bordet, og at de visioner og løfter for fremtiden, de skulle symbolisere, virkede hule. For Vanya stod det klart, at operahuset ikke blev bygget for ham, og for Zauri stod det klart, at hoteller og ejendomskomplekser ikke havde noget at gøre med hans personlige muligheder i fremtiden. Det er ikke som sådan bemærkelsesværdigt, at dele af en befolkning forholder sig skeptisk til statslige projekter. Det in- 
teressante i den georgiske kontekst er den ændring, der har fundet sted i forhold til graden af tro på statens visioner for fremtiden og på ideer om deres egen placering i denne. Snarere end at skabe håb for fremtiden skabte de det modsatte, nemlig ideer om, at alle grupper i samfundet ikke var samtidige, i den forstand at fremtiden ikke var for alle.

Under et besøg i Batumi i foråret 2010 stod byggetomten, hvor det lovede operahus skulle placeres, stadig tomt. Plakaten med billedet af operahuset var endda taget ned. Når jeg spurgte Vanya og andre lokale bekendte, hvorfor det endnu ikke var blevet bygget, svarede de med ligegyldighed, at planerne for operahuset for længst var blevet droppet, hvilket blev bekræftet af officielle kilder. De fleste var dog sikre på, at et nyt projekt snart ville blive proklameret, og at dette i sidste ende også ville falde til jorden igen. Mens staten igen og igen proklamerede nye planer, forblev fremtiden uvis for Vanya og mange af hans venner. Og hvis de lagde nogle planer, var det langs en fremtid, der drejede i en anden retning.

Søgeord: ungdom, fremtid, materialitet, Georgien, marginalisering

\section{Litteratur}

Alexander, Catherine, Victor Buchli \& Caroline Humphrey

2007 Urban Life in Post-soviet Asia. London: UCL Press.

Dudwick, Nora

2002 "No Guests at our Table". Social Fragmentation in Georgia. I: Dudwick et al. (eds.): When Things Fall Apart. Qualitative Studies of Poverty in the Former Soviet Union. Herndon: The World Bank.

Dunn, Elizabeth Cullen

2008 Postsocialist Spores. Disease, Bodies, and the State in the Republic of Georgia. American Ethnologist 35(2):243-58.

Frederiksen, Martin Demant

2011a (i tryk)Good Hearts or Big Bellies. Dzmak'atcoba and Images of Masculinity in the Republic of Georgia'. I: V. Amit \& N. Dyck (eds.): Young Men in Times of Uncertainty. Oxford: Berghahn Books.

2011b (i tryk)A Gate but Leading where? In Search of Actually Existing Cosmopolitanism in Post-soviet Tbilisi. I: C. Humphrey \& V. Skvirskaja (eds.): Explorations of the Post-cosmopolitan City. Oxford: Berghahn Books.

2009 Om at leve i skyggen. Jordens Folk - Etnografisk Revy 40(1):34-40.

2006 Invisible Suffering. Mental Illness, Social Annihilation and Violence in Contemporary Georgia. Kontur - Tidsskrift for Kulturstudier 14:47-53.

Hage, Ghassan

2003 Against Paranoid Nationalism. Searching for Hope in a Shrinking Society. London: Pluto Press.

Harvey, David

$2000 \quad$ Spaces of Hope. Edinburgh : Edinburgh University Press. 
Humphrey, Caroline

2002 The Unmaking of Soviet Life. Everyday Economics after Socialism. London:

Cornell University Press.

2007 New Subjects and Situated Interdependence. After Privatisation in Ulan-Ude.

I: C. Alxander et al. (eds.): Urban Life in Post-soviet Asia. London: UCL Press.

Koch, Erin

2006 Beyond Suspicion. Evidence, (Un)certainty, and Tuberculosis in Georgian Prisons.

American Ethnologist 33(1):50-62.

Kracauer, Siegfried

1969 History - the Last Thing before the Last. New York: Oxford University Press.

Le Moulec, Louis-Antoine

2010 Batumi under (Re)construction. Georgia Today, 2. april.

Louw, Maria

2011 (i tryk) A Maniac in Bishkek - or Why Serial Killers are Good to Think 'Transition' with. Ethnos.

Manning, Paul

2007 Rose-colored Glasses? Color Revolutions and Cartoon Chaos in Postsocialist

Georgia. Cultural Anthropology 22(2):171-213.

Mchedlishvili, Natalie

2009 Saakashvili Opens Construction of New Batumi Opera House. Georgia Today, 12. maj.

Miller, Daniel

2005 Materiality: An Introduction. I: D. Miller (ed.): Materiality. Durham \& London:

Duke University Press.

Montefiore, Simon Seebag

2005 Stalin. The Court of the Red Tsar. New York: Vintage Books.

Mühlfried, Florian

2010 Citizenship at War. Passports and Nationality in the 2008 Russian-Georgian

Conflict. Anthropology Today 20(2):8-13.

Nazpary, Joma

2001 Post-soviet Chaos. Violence and Dispossession in Kazakhstan. London: Pluto Press.

Oushakine, Serguei

2009 The Patriotism of Despair. Nation, War and Loss in Russia. London: Cornell University Press.

Pedersen, Morten Axel \& Lars Højer

2008 Lost in Transition. Fuzzy Property and Leaky Selves in Ulaanbaatar. Ethnos 73(1):73-96.

Pelkmans, Mathijs

2006 Defending the Border. Religion, Identity and Modernity in the Republic of Georgia. London: Cornell University Press.

Pinney, Christopher

2005 Things Happen - or, From What Moment Does that Object Come?

I: D. Miller (ed.): Materiality. Durham \& London: Duke University Press. 
Saakashvili, Mikheil

2004 Inaugurational Speech by President Mikheil Saakashvili. Hentet fra www.president.gov.ge 15.10.06.

Scott, James

1998 Seeing Like a State. How Certain Schemes to Improve the Human Condition Have Failed. New Haven \& London: Yale University Press.

Svašek, Maruška

2008 Postsocialism. Politics and Emotions in Central and Eastern Europe. Oxford:

Berghahn Books.

Thrift, Nigel

2004 Intensities of Feeling. Towards a Spatial Politics of Affect. Geografiska Annaler 86b(1):57-78.

Tsing, Anna Lowenhaupt

1993 In the Realm of the Diamond Queen. Marginality in an Out-of-the-way Place. Princeton: Princeton University Press.

Verdery, Katherine

1996 What Was Socialism and What Comes Next? Princeton: Princeton University Press.

Yampolsky, Mikheil

1995 In the Shadow of Monuments. Notes on Iconoclasm and Time. I: N. Condee (ed.): Soviet Hieroglyphics. Bloomington: Indiana University Press. 